\title{
Kepemilikan Hak Atas Tanah Terdaftar Atas Nama Anak yang Bersumber Dari Nominee Akta (Studi Putusan Nomor: 433k/Pdt/2016)
}

\author{
M. Takkas Siregar \\ Magang pada Kantor Notaris/PPAT Dr. Suprayitno., S.H., SpN., M.Kn \\ Kota Medan Sumatera Utara \\ E-Mail : takkassiregar1@gmail.com
}

\begin{abstract}
Abstrak
Perjanjian nominee yang dibuat oleh notaris memiliki ranah yang cukup luas dalam penggunaannya karena terdiri atas kuasa.Nominee pada dasarnya merupakan perjanjian yang tidak diatur secara tegas dan khusus, namun dalam kenyataan, dipakai sebagai perjanjian dengan pinjam nama yang keberadaannyabanyak menimbulkan dampak negatif dan kerugian terhadap para pihak jika akta ini tetap dibuat.Penelitian ini bertujuan untuk menganalisa pengaturan hukum terkait pembuatan akta notaris yang dikategorikan nominee akta, menganalisa kedudukan hukum hak atas tanah terdaftar atas nama anak yang bersumber dari nominee akta dan menganalisa terhadap putusan Mahkamah Agung Nomor 433K/Pdt/2016. Metode penelitian yaitu yuridis normatif, yang bersifat deskriptif analisis dengan teknik pengumpulan data studi kepustakaan. Fokus masalah berkenaan dengan kepemilikan hak atas tanah bersumber dari pinjam nama (nominee). Pengaturan hukum pembuatan akta Notaris dikategorikan Nominee akta dalam praktiknya banyak menimbulkan problem hukum. Maka dari itu, praktik pembentukannominee dibuat dengan perjanjian pendukung yang membangunhubungan hukum antar pihak,sehingga proses penyelundupan hukum terkesan sah danmemiliki dasar hukum. Berdasarkan hasil penelitian, penggunaan konsep nomineedalam kepemilikan tanah memiliki tujuan untuk menjaga kerahasiaan nama dan identitas asli dari khalayak umum dan pemerintah. Kedudukan hukumnyayaitu pembuatan nominee akta secara khusus tidak ada yang mengatur, namun di UUPM dan UUPT mengatur mengenai nominee. Analisis terhadap putusan ini yaitu hendaknya majelis hakim lebih teliti dalam menganalisa, memutus dan menyatakan putusan dengan melibatkan ahli yang berkompeten sehingga dapat didengar kesaksiannya sesuai keahlianya, untuk kemudian dapat dipedomani dalam mengambil suatu putusan dan putusan yang diambil oleh pengadilan dapat mencerminkan suatu perlindungan hukum yang adil bagi para pihak yang bersengketa di Indonesia.
\end{abstract}

Kata Kunci: Akta Pinjam Nama, Nominee, Notaris.

\section{ReClţ Review Vol. 2 No.2 Tahun 2020. E-ISSN: 2623-2928}




\begin{abstract}
Nominee Arrangement drafted by a Notary has quite wide range of usage because it contains authority. Nominee is principally an agreement that is not assertively specifically regulated, but in practice, it is used as an agreement with name borrowing which existence frequently brings negative impacts and financial loss to all parties if its deed is proceeded. The objective of this research was to analyze the legal regulations related to notarial deed drafting categorized into deed of nomination, the legal status of the land title registered with the name of a child mentioned in a nominee deed, and the Verdict of the Supreme Court Number 433K/Pdt/2016. Normative juridical research method is employed with descriptive analysis. The data are collected through library study. The research problems are about the land title ownership sourced from nominee or name borrowing. The legal regulations on notarial deeds that are categorized into deed of nomination causes many legal problems in practice; thus, the practice of nominee arrangement has to be made with a supporting agreement to build legal relationship among all parties, that the legal smuggling seems legitimate and has legal ground.The results demonstrate that the usage of nominee concept in land ownership is aimed at protecting the confidentiality of the true owner's name and identity from public and government. The legal status of deed of nomination is not specifically regulated, but the Law on Capital Market and Law on Limited Liability Companies stipulate regulations on nominee. The analysis result of this verdict is that the judges should be more conscientious in analyzing, deciding, and pronouncing the verdict by involving competent experts; it can be made guidance to make decision. The ruling issued by a court reflects a just legal protection for all disputed parties in Indonesia.
\end{abstract}

\title{
Keywords: $\quad$ Deed of Nomination, Nominee, Notary.
}

\section{Pendahuluan}

Notaris adalah pejabat umum yang berwenang untuk membuat akta autentik dan kewenangan lainnya, hal tersebut diatur dalam pasal 1 ayat (1) Undang-Undang Nomor 2 Tahun 2014 Tentang Perubahan Atas Undang-Undang Nomor 30 Tahun 2004 Tentang Jabatan Notaris (UUJN).Kebebasan berkontrak dalam pasal 1338 ayat (1) KUHPerdata mengatakan bahwa semua perjanjian yang dibuat secara sah berlaku sebagai undang-undang bagi mereka yang membuatnya. Kemudian ayat (3) mengatakan bahwa suatu perjanjian harus dilaksanakan dengan itikad baik. Pasal tersebut mengandung adanya asas kebebasan

\section{ReClţ}


berkontrak, asas pacta sund servanda ${ }^{l}$, asas kepastian hukum dan asas itikad baik(in good faith). ${ }^{2}$ Norma itikad baik ini merupakan salah satu sendi yang terpenting dari hukum perjanjian. ${ }^{3}$

Pasal 15 ayat (1) UUJN menyebutkan bahwa, notaris berwenang membuat akta autentik mengenai semua perbuatan perjanjian dan ketetapan yang diharuskan oleh peraturan perundang-undangan dan/atau yang dikehendaki oleh yang berkepentingan untuk dinyatakan dalam akta autentik, menjamin kepastian tanggal pembuatan akta, menyimpan akta, memberikan grosse, salinan dan kutipan akta, semuanya sepanjang pembuatan akta itu tidak juga ditugaskan atau dikecualikan kepada pejabat lain atau orang lain yang ditetapkan oleh undangundang.Jabatan yang diemban Notaris adalah suatu jabatan kepercayaan diberikan oleh undang-undang dan masyarakat, untuk itulah seorang Notaris bertanggung jawab untuk melaksanakan kepercayaan yang diberikan kepadanya dengan selalu menjunjung tinggi etika hukum dan martabat serta keluhuran jabatannya.Pada prinsipnya keabsahan akta notaris meliputi bentuk, isi, kewenangan pejabat yang membuat, serta pembuatannya pun harus memenuhi syarat yang telah ditentukan didalam peraturan perundang-undangan yang berlaku.Dengan demikian apabila sebuah akta tidak memenuhi persyaratan tersebut, maka tidak dapat dikategorikan sebagai akta autentik dan kekuatan pembuktiannya juga sangat lemah. ${ }^{4}$ Seorang notaris didalam menjalankan jabatannya harus dapat bersikap professional dengan dilandasi kepribadian yang luhur dengan senantiasa melaksanakan undang-undang sekaligus menjunjung tinggi kode etik profesinya yaitu Kode Etik Notaris. ${ }^{5}$

Berdasarkan Pasal 16 huruf (a) UUJN, seorang Notaris diharapkan dapat bertindak jujur, seksama, mandiri, tidak berpihak dan menjaga kepentingan pihak yang terkait dalam perbuatan hukum. Kemandirian Notaris harus sesuai asas legalitas hukum yang berlaku, sehingga Notaris dalam melaksanakan tugas tidak

${ }^{1}$ Asas Pacta Sund Servanda atau disebut juga sebagai asas kepastian hukum, berkaitan dengan akibat perjanjian atau perjanjian yang dibuat secara sah berlaku sebagai undang-undang merupakan asas bahwa hakim atau pihak ketiga harus menghormati substansi kontrak yang dibuat oleh para pihak, sebagaimana layaknya sebuah undang-undang. Sumber www.negarahukum.com/hukum/asas-asas-perjanjian.html, diakses pada tanggal 18 Agustus 2019, pukul 11.56 Waktu Indonesia Barat.

${ }^{2}$ Pengertian itikad baik dalam perjanjian adalah niat baik dari pihak-pihak yang melakukan suatu perjanjian untuk tidak merugikan mitra janjinya serta tidak merugikan kepentingan umum. (Sutan Remy: 1993). Sumber: http://www.definisimenurutparaahli.com/pengertian-itikad-baik/, diakses pada tanggal 18 Agustus 2019, pukul 16.57 Waktu Indonesia Barat.

${ }^{3}$ Subekti, Hukum Perjanjian, Intermasa, Jakarta, 1990, hlm.14.

${ }^{4}$ M.Edwin Azhari dan Djauhari, Tanggung Jawab Notaris Dalam Pembuatan Akta Perjanjian Nominee Dalam Kaitannya Dengan Kepemilikan Tanah Oleh Warga Negara Asing Di Lombok, Jurnal Akta Vol 5 Magister Kenotariatan Fakultas Hukum Unissula, 2018, hlm.45.

${ }^{5}$ Putri A.R, Perlindungan Hukum Terhadap Notaris (Indikator Tugas-Tugas Jabatan Notaris yang Berimplikasi Perbuatan Pidana), Sofmedia, Jakarta, 2011, hlm.5.

\section{ReCltevilew Vol. 2 No.2 Tahun 2020. E-ISSN: 2623-2928}


terpengaruh oleh pihak lain. Kemandirian yang dimaksud adalah bahwa dalam menjalankan jabatannya Notaris berada dalam kedudukan yang netral dan tidak memihak, artinya berada di luar para pihak yang melakukan hubungan hukum tersebut dan bukan sebagai salah satu pihak dalam hubungan hukum itu.

Pembuatan akta pinjam nama (Nominee) dalam hukum perjanjian di Indonesia dikategorikan sebagai perjanjian berindikasi menciptakan penyeludupan hukum. ${ }^{6}$ Perjanjian nominee atau akta pinjam nama yang dibuat oleh notaris memiliki ranah yang cukup luas dalam penggunaannya karena dalam akta nominee tersebut terdiri atas kuasa, di Indonesia praktek dari akta pinjam nama (nominee) masuk dalam ranah kepemilikan tanah dan juga kepemilikan dalam hukum perdata. Pada dasarnya perjanjian nominee merupakan perjanjian yang tidak diatur secara tegas dan khusus. Namun dalam kenyataannya, perjanjian nominee tersebut dipakai sebagai perjanjian dengan pinjam nama atau atas nama. ${ }^{7}$ Keberadaan akta pinjam nama (Nominee) pada prakteknya berhubungan dengan prinsip keadilan (the principle of justice) sebagai perwujudan nilai-nilai tertentu $^{8}$, yakni dengan melihat ada kepentingan dari para pihak dan juga keberadaan Notaris yang terlibat dalam pembuatan Aktanya yang juga tentunya menimbulkan kerugian-kerugian terhadap pihak yang bersangkutan jika akta ini tetap dibuat.Putusan Mahkamah Agung Nomor 433K/Pdt/2016, duduk permasalahan yang terjadi yaitu, Bapak CKK menikah bersama Ibu S secara sah dengan memiliki 3 (tiga) orang anak yang telah dewasa.Bapak CKK membeli 9 (Sembilan) bidang tanah dan bangunan, pembelian tersebut dipinjamnamakan/atas namakan (Nominee) Nyonya KG dan Nyonya KLG (Ny.KG dan Ny.KLG).Tanah dan Bangunan tersebut terletak di Provinsi Daerah Khusus Ibu Kota Jakarta, tepatnya di Kota Jakarta Barat dengan Sertifikat Hak Guna Bangunan.

Pembelian 9 (Sembilan) bidang tanah dan bangunan tersebut, diperuntukkan dan digunakan sebagai usaha Lokasari Sauna oleh CKK. Objek tanah dan bangunan tersebut dibeli dengan uangnya CKK, berdasarkan Akta Pernyataan dari Ny.KG dan Ny.KLG dihadapan Notaris TJ, yang membuktikan pembelian atas tanah dan bangunan berikut turutan-turutannya yang berdiri diatas bidang tanah sertifikat Hak Guna Bangunan (HGB) yang terletak di di Provinsi

${ }^{6}$ Penyeludupan Hukum adalah kaidah-kaidah hukum asing yang terkadang dikesampingkan menggunakan hukum nasional atau sebaliknya untuk keuntungan atau tujuan tertentu. Sumber: https://prezi.com/hnxfyetn5m-q/penyelundupan-hukum/, diakses pada tanggal 18 Agustus 2019, pukul 18.10 Waktu Indonesia Barat.

${ }^{7}$ Jaya Kesuma, Perjanjian Nominee Antara Warga Negara Indonesia Dengan Warga Negara Asing Dalam Praktik Jual Beli Tanah Dihubungkan Dengan Undang-Undang Pokok Agraria Nomor 05 Tahun 1960, Jurnal Unpas, 2016, hlm.6.

${ }^{8}$ M.Yazid Fathoni, Konsep Keadilan Dalam Pengelolaan Sumber Daya Alam Menurut Undang-Undang Pokok Agraria Tahun 1960, Jurnal IUS (Hukum dan Keadilan), Vol 1, No.1, April, 2013, hlm.46. 
Jakarta Barat, dipinjamnamakan (Nominee) Ny.KG dan Ny.KLG. Kemudian pembuktian 9 (Sembilan) bidang tanah dan bangunan tersebut adalah milik CKK, maka Ny.KG dan Ny.KLG telah menyatakan dalam Akta Pemberian Hak dan Kuasa kepada CKK dihadapan Notaris TJ. Dimana CKK diberikan hak untuk melakukan segala tindakan hukum atas 9 (Sembilan) bidang tanah dan bangunan tersebut.Tanah dan bangunan tersebut dikelola CKK bersama S.Akta Pemberian Hak dan Kuasa diatas menegaskan dalam substansinya yaitu, pemberian Hak dan Kuasa dari Ny.KG dan Ny.KLG kepada CKK, untuk mewakili Ny.KG dan Ny.KLG dalam segala hal dan untuk segala tindakan berkenaan 9 (Sembilan) bidang tanah dan bangunan yang diatas namakan (Nominee) tersebut. Serta, Akta Pemberian Hak dan Kuasa tersebut tidak bisa ditolak, dicabut dan dibatalkan.

Putusan Mahkamah Agung ini, menerangkan bahwa 17 (tujuh belas) hari sebelum CKK meninggal, Ny.KG dan Ny.KLG membuat pernyataan dalam Akta Penolakan, Pencabutan dan Pembatalan dihadapan Notaris SL tanpa ikut serta CKK. Inti Akta Penolakan, Pencabutan dan Pembatalan ini yaitu menolak, mencabut hak/kuasa atas hak atas tanah dan bangunan serta membatalkan dengan segala akibat hukum dan pelaksanaan Akta-Akta Pernyataan dan Akta Pemberian Hak dan Kuasa berkenaan 9 (Sembilan) bidang tanah dan bangunan yang telah dibuat bersama CKK sebelumnya.

Dalam hal ini yang jadi menarik bahwa Akta Pernyataan serta Akta Pemberian Hak dan Kuasa atas pembelian 9 (Sembilan) bidang tanah dan bangunan yang uangnya dari CKKdan meminjam nama (Nominee) Ny.KG dan Ny.KLG. Pengaturan hukum dalam kasus ini, kedudukan hukum hak atas tanah yang terdaftar bersumber dari Nominee akta, tanggung jawab Notaris serta Putusan Mahkamah Agung dalam kasus ini merupakan hal yang menarik untuk dianalisa dalam penelitian ini. Maka dari itu, dariuraian latar belakang diatas,penting untuk diteliti dan dikaji lebih lanjut dalam penelitianini, dengan mengangkat judul Analisis Yuridis Kepemilikan Hak Atas Tanah Terdaftar Atas Nama Anak Yang Bersumber Dari Nominee Akta (Studi Putusan Nomor: 433K/Pdt/2016).

Berdasarkan uraian-uraian pada latar belakang tersebut diatas, maka permasalahan yang akan diangkat dalam penelitian ini adalah:

1. Bagaimana pengaturan hukum terkait pembuatan akta notaris yang dikategorikan nominee akta?

2. Bagaimana kedudukan hukum hak atas tanah yang terdaftar atas nama anak yang bersumber dari nominee akta?

3. Bagaimana analisis terhadap Putusan Mahkamah Agung Nomor 433K/Pdt/2016 atas pembuatan akta pinjam nama? 
Berdasarkan permasalahan yang telah dikemukakan di atas, maka tujuan yang hendak dicapai dalam penelitian ini adalah:

1. Untuk mengetahui dan menganalisa pengaturan hukum terkait pembuatan akta notaris yang dikategorikan nominee akta;

2. Untuk mengetahui dan menganalisa kedudukan hukum hak atas tanah yang terdaftar atas nama anak yang bersumber dari nominee akta; dan

3. Untuk mengetahui dan menganalisa terhadap Putusan Mahkamah Agung Nomor 433K/PDT/2016 atas pembuatan akta pinjam nama.

\section{Metode Penelitian}

Metode ini menggunakan metode penelitian yuridis normatif yaitu dengan menekankan pada data-data sekunder dengan mempelajari dan mengkaji asas-asas hukum positif yang berasal dari data kepustakaan dan perbandingan hukum, serta unsur-unsur atau faktor-faktor yang berhubungan dengan judul penelitian ini.

Alasan penelitian yuridis normatif ini digunakan karena hendak meneliti normahukum tentang kepemilikan hak atas tanah terdaftar atas nama anak yang bersumber dari nominee akta.Penelitian ini bersifat deskriptif analisis, yaitu menggambarkan secara sistematis faktual dan akurat tentang permasalahan penegakan hukum atas terjadinya pembuatan akta pinjam nama (nominee) dalam praktek notaris. Penelitian yuridis normatif atau penelitian yang menganalisis hukum, baik yang tertulis dalam buku maupun hukum yang diputuskan oleh hakim melalui proses pangadilan (Litigation). ${ }^{9}$ Pendekatannya deskriptif analisis, penelitian normatif meliputi asas hukum, sinkronisasi hukum, perbandingan hukum serta sejarah hukum. ${ }^{10}$

Teknik pengumpulan yang peneliti lakukan dengan studi kepustakaan. Studi Kepustakaan (Library Research) adalah penelitian yang dilakukan dengan cara meneliti bahan pustaka untuk memperoleh data sekunder berupa buku-buku baik koleksi pribadi maupun dari perpustakaan, artikel baik yang diambil dari media cetak maupun media elektronik, dokumenpemerintah. termasuk peraturan perundang-undangan. Hasil dari kegiatan pengkajian tersebut kemudian dibuat ringkasan secara sistematis sebagai inti sari hasil pengkajian studi dokumen. Tujuan dan teknik dokumentasi ini adalah untuk mencari konsepsi-konsepsi, teoriteori, pendapat-pendapat atau penemuan-penemuan yang berhubungan dengan

${ }^{9}$ Bismar Nasution, Metode Penelitian Hukum Normatif dan Perbandingan Hukum, Makalah FH USU, tanggal 18 Februari 2003, hlm.1.

${ }^{10}$ Bambang Waluyo, Penelitian Hukum Dalam Praktek, Sinar Grafika, Jakarta, 1991, H.15. 
permasalahan penelitian. ${ }^{11}$ Sumber data penelitian menggunakan data primer dan data sekunder.

a. Bahan Hukum Primer, yaitu bahan hukum yang bersifat mengikat yang terdiri dari:

1) Undang - Undang Dasar Negara Republik Indonesia 1945;

2) Kitab Undang-Undang Hukum Perdata;

3) Undang-Undang Nomor 5 Tahun 1960 Tentang Peraturan Dasar Pokok-Pokok Agraria;

4) Undang-Undang Nomor 2 Tahun 2014 Tentang Perubahan Atas Undang-Undang Nomor 30 Tahun 2004 Tentang Jabatan Notaris;

5) Putusan Mahkamah Agung Nomor 433K/Pdt /2016;

6) Peraturan Perundang Undang lainnya yang berkaitan dengan penelitian ini.

Adapun hasil yang langsung dikumpulkan oleh peneliti dari sumber pertanyaan dengan metode wawancara, yaitu sebagai informan dalam penelitian ini adalah beberapa Notaris yang ada di Kota Medan.

b. Bahan Hukum Sekunder, yaitu bahan hukum yang memberikan petunjuk serta penjelasan terhadap bahan hukum primer, yang terdiri dari buku, literatur, jurnal, hasil penelitian, dan karya ilmiah lainnya yang berhubungan dengan penelitian ini.

c. Bahan Hukum Tersier, yaitu bahan hukum yang memberikan petunjuk dan penjelasan terhadap bahan hukum primer dan bahan hukum sekunder yang terdiri dari kamus umum bahasa Indonesia dan kamus hukum. Penelitian ini menggunakan bahan kepustakaan sebagai tumpuan utamanya, yang berarti akan cenderung pada penelaahan dan penyajian data primer dan data sekunder yang diperoleh dari bahan kepustakaan sehingga tidak diperlukan penyusunan atau perumusan hipotesa. ${ }^{12}$

\section{Pembahasan}

\section{A. Pengaturan Hukum Terkait Pembuatan Akta Notaris Yang Dikategorikan}

\section{Nominee Akta}

Pengaturan hukum terkait pembuatan akta Notaris yang dikategorikan Nominee akta sendiri dalam praktiknya banyak menimbulkan problem hukum dan pihak pejabat yang membuat akta tersebut sebenarnya undang-undang ada

\footnotetext{
${ }^{11}$ Edy Ikhsan, Mahmul Siregar, Metode Penelitian Dan Penulisan Hukum Sebagai Bahan Ajar, Fakultas Hukum Universitas Sumatera Utara, Medan, 2009, hlm.24

${ }^{12}$ Soerjono Soekanto dan Sri Mamudji, Penelitian Hukum Normatif: Suatu Tinjauan Singkat, Rajawali Pers, Jakarta 1990, hlm.53.
} 
mengatur tentang larangan notaris dalam kaitannya praktik Nominee akta. Larangan notaris merupakan suatu tindakan yang dilarang untuk dilakukanoleh notaris. ${ }^{13}$ Jika larangan ini dilanggar oleh notaris, maka kepada notaris yangmelanggar akan dikenakan sanksi sebagaimana yang tersebut dalam pasal 85 Undang-Undang Jabatan Notaris (UUJN). ${ }^{14}$

Dasar berlakunya konsep pinjam nama (nominee) di Indonesia bukan didasarkan pada suatu peraturan hukum, melalinkanberdasarkan pada suatu perjanjian Innominat yang berlaku karena adanya pasal 1338 Kitab UndangUndang Hukum Perdata/KUHPerdata. Akan tetapi, karena adanya praktik struktur nominee hak atas tanah merupakan hal yang bertentangan dengan hukum, maka pada praktik pembentukanstruktur nominee tersebut dibuat dengan perjanjian pendukung yang membangunhubungan hukum antara para pihak.

Dalam praktik penyelundupan hukum struktur nominee hak atas tanah, perjanjian yang membentuk struktur nominee hak atas tanah dapat dibuat secara langsung menyatakan adanya kepemilikan ganda atas atas tanah yangdiperjanjikan,namun dapat juga dibuat dengan membuat perjanjian yang secaratidak langsungmembentuk struktur nominee hak atas tanah. Notaris mempunyai tugas utama yang berat, selain harus memberikan pelayanan kepada masyarakat dengan sebaik-baiknya, juga harus mempertanggung jawabkan perbuatan hukum yang dilakukannya baik selama menjabat sebagai notaris maupun sesudah pensiun jadi Notaris. ${ }^{15}$

Nominee agreement lahir dari adanya asas kebebasan berkontrak dalam hukum perjanjian, dan karenanya termasuk perjanjian yang tidak diatur di dalam undang-undang karena belum terdapat pengaturan secara khusus mengenai konsep nominee. Dengan demikian nominee agreement dapat dikategorikan sebagai perjanjian tidak bernama (innominaat) yang timbul berdasarkan asas kebebasan berkontrak (pacta sunt servanda) dan itikad baik para pihak. Nominee Agreement ditinjau dari 3 (tiga) aspek, yaitu: kebebasan untuk membuat perjanjian, kebebasan untuk menentukan isi perjanjian dan kebebasan untuk menandatangani perjanjian. Ketiga aspek tersebut merupakan perwujudan dari asas kebebasan berkontrak dan asas kekuatan mengikat sebagaimana diatur dalam Pasal 1320 KUHPerdatajuncto Pasal 1338 ayat (1) KUHPerdata.Tujuan dari penggunaan nominee dalam kepemilikan kepemilikan tanah yaitu untuk mengatasi pembatasan-pembatasan yang ditetapkan oleh pemerintah Indonesia. Secara garis

${ }^{13}$ Ihdina Nida Marbun, Tanggung Jawab Notaris Terhadap Covernote (Surat Keterangan) Atas Pengurusan Sertipikat, Tesis Magister Kenotariatan, Universitas Sumatera Utara, 2015, hlm.49.

${ }^{14}$ Habib Adjie, Sekilas Dunia Notaris \& PPAT Indonesia, Mandar Maju, 2009, H.90.

${ }^{15}$ Fransiskus Sinaga, Prinsip Kemandirian Notaris Dalam Pembuatan Akta Otentik, Tesis Magister Kenotariatan, Universitas Sumatera Utara, 2013, hlm.7. 
besar dapat dilihat bahwa tujuan dari penggunaan nomineedalam kepemilikan tanah adalah agar agar nama dan identitas dari pihak beneficiary tidak diketahui oleh khalayak umum dan pemerintah.

Pasal 38 ayat (3) huruf c UUJN ditegaskan bahwa isi akta merupakan kehendak para pihak. Namun, kehendak para pihak tidak semua dapat diaminkan oleh Notaris, tetapi jika ada suatu sebab yang karena hukum bertentangan, maka Notaris harus menolak apa yang dikehendaki penghadap. Pada larangan Nominee akta ini, menjadi larangan dibuatnya Nominee akta dalam praktek jabatan Notaris, dikarenakan dalam kasus ini, Notaris SL membuat akta penolakan, pencabutan dan pembatalan hanya dihadapan satu pihak saja, yaitu Nyonya KG dan KLG tanpa dihadirkan atau tanpa sepengetahuan Tuan CKK. Sehingga dalam hal ini Notaris SL dikategorikan melanggar profesionalitas dan bertentangan dengan pasal 16 ayat (1) huruf a UUJN yaitu "dalam menjalankan jabatannya, Notaris wajib bertindak amanah, jujur, saksama, mandiri, tidak berpihak dan menjaga kepentingan pihak yang terkait dalam perbuatan hukum”.Praktik Nomineearrangement(pengaturan pinjam nama) dilarang oleh Undang-Undang Nomor 25 Tahun 2007 Tentang Penanaman Modal (UUPM).

Dalam menjalankan jabatannya, sudah selayaknya notaris yang mengetahui niat penghadap untuk membuat perjanjian yang membentuk stuktur nominee kepemilikan hak atas tanah dalam rangkaian transaksi jual beli hak atas tanah harus bersikap agar pihak yang hendak membuat perjanjian tersebut karena ketidak tahuan akan akibat hukum pembuatan perjanjian yang membentuk stuktur nomineekepemilikan hak atas tanah harus diberikan penjelasan dan penyuluhan hukum agar mengurungkan niatnya tersebut. Sedangkan bagi pihak yang dengan sengaja hendak membuat perjanjian tersebut dengan niatannya sendiri walaupun telah mengetahui akibat hukumnya maka notaris dapat menolak memberi pelayanan hukum (Pasal 16 ayat (1) huruf d) dan secara sadar tunduk pada kode etik notaris agar tidak tergiur dengan tawaran imbalan yang besar.

\section{B. Kedudukan Hukum Hak Atas Tanah Yang Terdaftar Atas Nama Anak YangBersumber Dari Nominee Akta}

Perjanjian nominee dengan pemberian kuasa pada umumnya adalah sama karena keduanya memerlukan pihak yang berperan sebagai pemberi kuasa dan penerima kuasa. Namun apabila dikaji secara seksama, keduanya merupakan hal yang serupa tetapi tidak sama. Perjanjian nominee dari sifatnya adalah sama dengan perjanjian timbal balik, dimana para pihak memiliki kewajiban untuk memenuhi prestasi masing-masing pihak yang tercantum di dalam perjanjian.Berkenaan dengan hak dan kewajiban para pihak dalam nominee akta, berdasarkan Pasal 1338 ayat (1) KUHPerdata. 
Kata-kata "berlaku sebagai undang-undang bagi mereka yang membuatnya" mengatakan, bahwa perjanjian seperti itu mengikat para pihak dan karenanya para pihak harus memenuhi janji-janjinya. Arti seperti itu diungkapkan dengan mengatakan: perjanjian berlaku sebagai undang-undang bagi mereka yang menutupnya. ${ }^{16}$ Seperti undang-undang mengatur hak dan kewajiban anggota masyarakat pada umumnya, demikian juga perjanjian menetapkan hak dan kewajiban di antara para pihak dalam perjanjian. Kata-kata "yang membuatnya" tertuju kepada para pihak dalam perjanjian.Disebutkan diatas mengikat "sebagai undang-undang", maksudnya adalah sebagaimana undang-undang mengikat anggauta masyarakat, demikian juga perjanjian mengikat, hanya bedanya, undang-undang mengatur anggota masyarakat pada umumnya, sedang perjanjian hanya mengatur hak dan kewajiban antara para pihak dalam perjanjian berdasarkan pasal 1340 KUHPerdata.Kata-kata "yang dibuat secara sah" mengingatkan kita pada Pasal 1320 KUHPerdata, yang dalam doktrin ditafsirkan sebagai suatu ketentuan yang mengatur syarat sahnya suatu perjanjian. Berdasarkan pasal itu, suatu perjanjian sah, kalau memenuhi syarat yang disebutkan di sana.

Notaris bertanggungjawab supaya setiap akta yang dibuatnya mempunyai sifat autentik sebagaimana yang dimaksud dalam Pasal 1868 KUHPerdata.Kewajibannotaris untuk dapat mengetahui peraturan hukum yang berlaku di Negara Indonesiajuga serta untuk mengetahui hukum apa yang berlaku terhadap para pihak yang datang kepada notaris untuk membuat akta. Hal tersebut sangat penting agar supaya akta yang dibuat oleh notaris tersebut memiliki autentisitasnya sebagai akta autentikkarena sebagai alat bukti yang sempurna.Namun dapat saja notaris melakukan suatukesalahan dalam pembuatan akta.

Kesalahan-kesalahan yang terjadi pada akta-akta yang dibuat oleh notaris akan dikoreksi oleh hakim pada saat akta notaris tersebut diajukan ke pengadilan sebagai alat bukti. Kewenangan dari hakim untuk menyatakan suatu akta notaris tersebut batal demi hukum, dapat dibatalkan atau akta notaris tersebut dinyatakan tidak mempunyai kekuatan hukum. Tindakan pelanggaran yang dilakukan oleh notaris terhadap ketentuan-ketentuan Pasal 16 (1) huruf i. Pasal 16 (1) huruf k, Pasal41, Pasal 44, Pasal 48, Pasal 49, Pasal 50, Pasal 51, Pasal 52 UUJN, yang menyebabkan suatu akta hanya mempunyai kekuatan pembuktian sebagai akta di bawah tangan atau akta menjadibatal demi hukum, maka pihak yang merugikan

${ }^{16}$ C. Asser - L.E.H. Rutten, Handleiding tot de broefening van het Nederlands Burgelijk Recht,Verbintenissenrecht, Algemene Leer der overeenkomsten, hlm.225. Kutipan dalam website halaman link https://m.hukumonline.com/berita/baca/lt5a5c2fbdae8c4/pelaksanaan-suatuperjanjian/, diakses pada tanggal 26 Desember 2019, Pukul 04.53 Waktu Indonesia Barat.

\section{ReCltel}


dapat menuntut penggantian biaya,ganti rugi dan bunga pada notaris. Kendala dilain sisi, Notaris juga dituntut, dituntut terhadap penggantian biaya, dan ganti rugi sebagai akibat akta Notaris mempunyai kekuatan pembuktian bila aktanya dibawah tangan atau batal demi hukum.

\section{Analisis Terhadap Putusan MahkamahAgungNomor 433k/Pdt/2016 Atas Pembuatan AktaPinjam Nama}

Putusan Mahkamah Agung Nomor 433K/Pdt/2016, duduk permasalahan yang terjadi yaitu, Bapak CKK menikah bersama Ibu $S$ (penggugat) secara sah dengan memiliki 3 (tiga) orang anak yang telah dewasa.Bapak CKK membeli 9 (Sembilan) bidang tanah dan bangunan, pembelian tersebut dipinjamnamakan/atas namakan (Nominee) Nyonya KG dan Nyonya KLG (Ny.KG dan Ny.KLG).Tanah dan Bangunan tersebut terletak di Provinsi Daerah Khusus Ibu Kota, Kota Jakarta Barat dengan Sertifikat Hak Guna Bangunan.

Pembelian 9 (Sembilan) bidang tanah dan bangunan tersebut, diperuntukkan dan digunakan sebagai usaha Lokasari Sauna oleh CKK. Objek tanah dan bangunan tersebut dibeli dengan uangnya CKK, berdasarkan Akta Pernyataan dari Ny.KG dan Ny.KLG dihadapan Notaris TJ, yang membuktikan pembelian atas tanah dan bangunan berikut turutan-turutannya yang berdiri diatas bidang tanah sertifikat Hak Guna Bangunan (HGB) yang terletak di di Provinsi Jakarta Barat, dipinjamnamakan (Nominee) Ny.KG dan Ny.KLG. Kemudian pembuktian 9 (Sembilan) bidang tanah dan bangunan tersebut adalah milik CKK, maka Ny.KG dan Ny.KLG telah menyatakan dalam Akta Pemberian Hak dan Kuasa kepada CKK dihadapan Notaris TJ.Dimana CKK diberikan hak untuk melakukan segala tindakan hukum atas 9 (Sembilan) bidang tanah dan bangunan tersebut.Tanah dan bangunan tersebut dikelola CKK bersama Ny.S. Akta Pemberian Hak dan Kuasa diatas menegaskan dalam substansinya yaitu, pemberian Hak dan Kuasa dari Ny.KG dan Ny.KLG kepada CKK, untuk mewakili Ny.KG dan Ny.KLG dalam segala hal dan untuk segala tindakan berkenaan 9 (Sembilan) bidang tanah dan bangunan yang diatas namakan (Nominee) tersebut. Serta, Akta Pemberian Hak dan Kuasa tersebut tidak bisa ditolak, dicabut dan dibatalkan.

Putusan Mahkamah Agung ini, menerangkan bahwa 17 (tujuh belas) hari sebelum CKK meninggal, Ny.KG dan Ny.KLG membuat pernyataan dalam Akta Penolakan, Pencabutan dan Pembatalan dihadapan Notaris SL tanpa ikut serta CKK. Inti Akta Penolakan, Pencabutan dan Pembatalan ini yaitu menolak, mencabut hak/kuasa atas hak atas tanah dan bangunan serta membatalkan dengan segala akibat hukum dan pelaksanaan Akta-Akta Pernyataan dan Akta Pemberian Hak dan Kuasa berkenaan 9 (Sembilan) bidang tanah dan bangunan yang telah 
dibuat bersama CKK sebelumnya.Akta Penolakan, Pencabutan dan Pembatalan sendiri memiliki akibat yang pada prinsipnya sama antara batal demi hukum, dapat dibatalkan atau non existent yaitu ketiganya mengakibatkan perbuatan hukum tersebut menjadi tidak berlaku atau perbuatan hukum tersebut tidak memiliki akibat hukumnya atau tiadanya sesuatu yang esensi/pokok dalam perjanjian tersebut. ${ }^{17}$ Analisis pertimbangan hakim dalam putusan Mahkamah Agung Nomor 433K/Pdt/2016 ini, yaitu bahwa dalam pokok perkaranya memiliki harta bersama, Ny.S memiliki hak dikarenakan Ny.S adalah isteri sah dari Tuan CKK yang dalam hal ini tanah objeknya hasil dari harta bersama. Ny.S memiliki hak karena merupakan pasangan hidup dan juga bertindak ahli waris, dalam hal ini memiliki 2 (dua) alasan yang cukup kuat dalam bagian hak atas tanah yang diperkarakan dalam putusan Mahkamah Agung Nomor 433K/Pdt/2016. Perkara tersebut dari tingkat Pengadilan Negeri (PN) hingga kasasi tidak mempertimbangkan akta yang dibuat oleh Ny.KG dan Ny.KLG berupa Akta pernyataan serta Akta Pemberian Hak dan Kuasa yang dibuat bersama-sama dengan Bapak CKK dan Ny.S. Padahal, akta tersebut dibuat dihadapan Notaris yang memiliki kekuatan hukum terkuat dan sah dimata hukum berdasarkanpasal 15 Undang-Undang Nomor 2 Tahun 2014 Tentang Jabatan Notaris (UUJN).

Hakim mengabaikan permohonan penggugat (Ny.S) dan tidak mempertimbangkan pertimbangan hakim dalam perkara putusan Mahkamah Agung Nomor 433K/Pdt/2016. Bahwa Akta Penolakan, Pencabutan dan Pembatalan yang dibuat Ny.KG dan Ny.KLG Nomor 104 dan 105 yang dibuat dihadapan Notaris SL sebenarnya bertentangan dengan hukum berdasarkan putusan Mahkamah Agung Nomor 433K/Pdt/2016 halaman 17, dikarenakan klausul Akta Pernyataan serta Akta Pemberian Hak dan Kuasa yang dibuat Ny.KG dan Ny.KLG bersama Bapak CKK dan Ny.S tidak dapat dibatalkan dan akta tersebut telah ditentukan, digariskan dan dinyatakan Ny.KG dan Ny.KLG memberikan hak dan wewenang sepenuhnya kepada Bapak CKK untuk memiliki dan menguasai 9 (sembilan) bidang tanah dan bangunan. Serta, dalam akta diatas Ny.KG dan Ny.KLG telah memberikan kuasa kepada Bapak CKK, kuasa mana tidak dapat dicabut kembali sebab-sebab atau alasan-alasan yang tercantum dalam pasal 1813 KUHPerdata.Pembuatan Akta Penolakan, Pencabutan dan Pembatalan diatas dibuat tidak melibatkan Bapak CKK dan Ny.S yang secara istilah hukumnya pembuatan akta tersebut dibuat dengan sepihak/tidak melibatkan pihak yang berkompeten dalam perkara kasus ini. Oleh karena itu, Akta Penolakan,

\footnotetext{
${ }^{17}$ Mujib Medio Annas, Analisis Yuridis Kepemilikan Hak Atas Tanah Yang Di Peroleh Berdasarkan Akta Jual Beli Yang Bersumber Dari Akta Perjanjian Pengikatan Jual Beli Dan Akta Kuasa Jual Yang Telah Dibatalkan (Studi Putusan Mahkamah Agung Nomor 1681K/Pdt/2015), Tesis Magister Kenotariatan, Universitas Sumatera Utara, 2019, hlm.112.
} 
Pencabutan dan Pembatalan Nomor 104 yang dibuat dihadapan Notaris SL cacat hukum dan harus dibatalkan.

Bahwa memang betul Bapak CKK membeli 9 (sembilan) objek tanah dana bangunan yang berada di Jakarta Barat dengan meminjam nama (nominee) Ny.KG dan Ny.KLG. tetapi Ny.KG dan Ny.KLG membuat pernyataan serta memberikan hak dan kuasa kepada Bapak CKK, sehingga dalam hal ini Ny.KG dan Ny.KLG hanya dipinjam namakan saja, tanpa menguasai penuh objek tanah tersebut diatas. Bahwa Akta Penolakan, Pencabutan dan Pembatalan Nomor 105 yang dibuat dihadapan Notaris SL yang intinya menolak, mencabut kuasa/hak atas tanah dan bangunan serta membatalkan dengan segala akibat hukum dan pelaksanaan Akta Pernyataan serta Akta Pemberian Hak dan Kuasa yang dalam hal ini menurut hukum bertentangan dengan hukum atau cacat hukum karena, dalam akta tersebut disebutkan/dinyatakan Ny.KG dan Ny.KLG bertindak untuk diri sendiri dan selaku kuasa Bapak CKK dihadapan Notaris SL. Padahal, Bapak CKK tidak pernah memberikan kuasa kepada Ny.KG dan Ny.KLG untuk membatalkan semua akta-akta yang dibuat dihadapan Ny.KG dan Ny.KLG dihadapan Notaris SL.

Penjelasan diatas menerangkan bahwa tindakan Ny.KG dan Ny.KLG sangat merugikan Ny.S dikarenakan Ny.S adalah isteri sah dari Bapak CKK dan 9 (sembilan) objek tanah dan bangunan yang diperkarakan tersebut diatas digunakan untuk usaha sauna dan Ny.KG dan Ny.KLG tidak mau memberikan sertipikat aslinya kepada Ny.S dan memaksa keluar dari objek sengketa dikarenakan sertipikatnya dipegang mereka dan juga atas nama mereka setelah Bapak CKK meninggal dunia. Padahal sertipikat itu menerangkan bahwa pinjam nama (nominee) yang alas haknya Hak Guna Bangunan (HGB) dibeli dengan uang Bapak CKK dan hanya meminjam nama (nominee) Ny.KG dan Ny.KLG berdasarkan Akta Pernyataan serta Akta Pemberikan Hak dan Kuasa dibuat bersama-sama dengan Bapak CKK dan Ny.S dihadapan Notaris TJ. Akan tetapi, Ny.KG dan Ny.KLG tidak memberikan sertipikat aslinya dan malah menyuruh keluar Ny.S dan berbuat semaunya dikarenakan 17 (tujuh belas) hari sebelum Bapak CKK meninggal dunia, Ny.KG dan Ny.KLG membuat Akta Penolakan, Pencabutan dan Pembatalan Nomor 104 dan 105 dihadapan Notaris SL tanpa sepengetahuan Bapak CKK dan Ny.S. Artinya, Ny.KG dan Ny.KLG membuat akta tersebut sepihak tanpa turut ikut hadir dan mengetahui pembuatan akta tersebut.

Pembatalan akta yang dilakukan Ny.KG dan Ny.KLG ini seharusnya batal demi hukum karena Perjanjian adalah suatuperbuatan dengan mana satu orang atau lebih mengikatkan dirinya terhadap satu orang lain atau lebih berdasarkan pasal 1313 Kitab Undang-Undang Hukum Perdata (KUHPerdata). Menurut 
KUHPerdata Syarat batal dianggap selalu dicantumkan dalam persetujuan yang timbal balik, andaikata salah satu pihak tidak memenuhi kewajibannya.Dalam hal demikian persetujuan tidak batal demi hukum, tetapi pembatalan harus dimintakan kepada Pengadilan.Permintaan ini juga harus dilakukan, meskipun syarat batal mengenai tidak dipenuhinya kewajiban dinyatakan di dalam persetujuan. Jika syarat batal tidak dinyatakan dalam persetujuan, maka seharusnya Hakim dengan melihat keadaan, atas permintaan tergugat, leluasa memberikan suatu jangka waktu untuk memenuhi kewajiban, tetapi jangka waktu itu tidak boleh lebih dan satu bulan berdasarkan pasal 1266 KUHPerdata.

Perjanjian tersebut mengikat pihak-pihaknya, dan tidak dapat ditarik kembali atau dibatalkan secara sepihak saja.Jika ingin menarik kembali atau membatalkan itu harus memproleh persetujuan pihak lainnya, jadi diperjanjikan lagi.Namun demikian, apabila ada alasan-alasan yang cukup menurut undangundang, perjanjian dapat ditarik kembali atau dibatalkan secara sepihak. ${ }^{18}$ Perjanjian yang batal mutlak dapat juga terjadi jika suatu perjanjian yang dibuat tidak dipenuhi, padahal aturan hukum sudah menentukan untuk perbuatan hukum tersebut harus dibuat dengan cara yang sudah ditentukan atau berlawanan dengan kesusilaan atau ketertiban umum karena perjanjian sudah dianggap tidak ada, maka sudah tidak ada dasar lagi bagi para pihak untuk saling menuntut atau menggugat dengan cara dan bentuk apapun. ${ }^{19}$ Dalam pembatalan akta dari nominee akta yang dibuat oleh para pihak, jika sepakat untuk membatalkan nya maka dapat membatalkan dengan cara membuat akta pembatalan atas akta sebelumnya oleh notaris, tetapi jika pembatalan dilakukan oleh satu pihak maka pembatalan tersebut akan dilkakukan melalui gugatan di pengadilan. Perjanjian yang sah tidak dapat ditarik kembali secara sepihak.

\section{Penutup}

\section{A. Kesimpulan}

1. Pengaturan hukum terkait pembuatan akta Notaris yang dikategorikan nominee akta, yaitu pembuatan nominee akta sendiri secara khusus tidak ada yang mengaturnya atau dengan kata lain nominee akta tidak ada pengaturan hukumnya secara rinci dan mendetail. Kedudukan hak atas tanah secara hukum tidak melanggar dengan ketentuan hukum yang berlaku tetapi konteks nominee sendiri yang menjadi permasalahan dalam ruang lingkup kepemilikan hak atas tanah.Nominee akta sendiri memiliki akibat hukum, yaitu dapat dibatalkan

${ }^{18}$ Subekti, Pokok -Pokok Hukum Perdata, Cet. 24, PT. Intermassa, Jakarta, 1992, hlm.80.

${ }^{19}$ Peter Mahmud Marzuki, Batas-Batas Kebebasan Berkontrak, Fakultas Hukum Universitas Airlangga, Volume 18, Nomor 3, Mei 2003, hlm.203.

\section{ReCltevil Vol. 2 No.2 Tahun 2020. E-ISSN: 2623-2928}


karena adanya pihak yang merasa dirugikan dengan adanya praktik pinjam nama (nominee) tersebut.

2. Kedudukan hukum hak atas tanah yang terdaftar yang bersumber dari nominee akta, yaitudalam penggunaan konsep nomineedalam kepemilikan tanah oleh seseorang memiliki tujuan yaitu untuk menjaga kerahasiaan nama dan identitas asli dari pihak yang memiliki benda tersebut dari khalayak umum dan pemerintah Indonesia, sehingga pihak yang diakui dan memiliki kedudukan secara hukum adalah pihak nominee. Tujuan lain yang tentunya ingin dicapai dalam penggunaan nominee adalah untuk menghindari pembatasan-pembatasan yang ditetapkan oleh pemerintah Indonesia sebagaimana dinyatakan dalam peraturan perundang-undangan yang berlaku.

3. Analisis terhadap putusan Mahkamah Agung nomor 433K/Pdt/2016 atas pembuatan akta pinjam nama (nominee), yaitu Pertimbangan hukum hakim dalam pembuatan akta pinjam nama berdasarkan putusan Mahkamah Agung nomor 433K/Pdt/2016 yang berkekuatan hukum tetap (Inkrah), bahwa gugatan dari penggugat dinyatakan ditolak, hakim berpendapat bahwa kepemilikan 9 (sembilan) objek hak atas tanah dan bangunan yang disengketakan sebenarnya milik Ny.KG dan Ny.KLG berdasarkan asas publisitas, yaitu nama yang tertuang dalam sertipikat adalah pemilik sah dari suatu objek bidang tanah dan bangunan.

\section{B.Saran}

1. Notaris seharusnya mengetahui maksud dan tujuan penghadap, untuk membuat perjanjian yang membentuk stuktur nominee kepemilikan hak atas tanah dan harus bersikap professional, serta harus memberikan penjelasan dan penyuluhan hukum kepada para penghadap. Sedangkan bagi pihak yang dengan sengaja hendak membuat perjanjian nominee dengan niatannya sendiri walaupun telah mengetahui akibat hukumnya, maka Notaris dapat menolak memberi pelayanan hukum (Pasal 16 ayat (1) huruf d) dan secara sadar tunduk pada kode etik notaris agar tidak tergiur dengan tawaran imbalan yang besar.

2. Kepada Notaris hendaknya lebih professional dalam mengetahui kedudukan hak atas tanah yang terdaftar yang bersumber dari nominee akta sesuai kode etik dan berdasarkan UUJN. Kepada penghadap seharusnya mengetahui kedudukan hak dan kewajiban para pihak dalam pembuatan akta serta lebih mengedepankan dampak dari akta yang akan dibuat oleh para penghadap sebelum membuat akta, apalagi membuat akta

\section{ReC}


yang bertentangan dengan hukum dan banyak menimbulkan dampak negatif kedepannya.

3. Hendaknya majelis hakim lebih teliti dalam menganalisa, memutus dan menyatakan dalam putusan Mahkamah Agung nomor 433K/Pdt/2016 yang berkekuatan hukum tetap (Inkrah)melibatkan ahli yang berkompeten dibidang pertanahan yang disengketa tersebut sehingga dapat didengar kesaksiannya sesuai keahlianya, untuk kemudian dapat dipedomani dalam mengambil suatu putusan sehingga putusan yang diambil oleh pengadilan dapat mencerminkan suatu perlindungan hukum yang adil bagi para pihak yang bersengketa dalam praktik pertanahan di Indonesia.

\section{Daftar Pustaka}

\section{Buku}

Bambang Waluyo. 1991.Penelitian Hukum Dalam Praktek. Sinar Grafika. Jakarta.

Edy Ikhsan, Mahmul Siregar. 2009.Metode Penelitian Dan Penulisan Hukum Sebagai Bahan Ajar, Fakultas Hukum Universitas Sumatera Utara. Medan. Habib Adjie. 2009.Sekilas Dunia Notaris \& PPAT Indonesia. Mandar Maju.

M.Yazid Fathoni. 2013.Konsep Keadilan Dalam Pengelolaan Sumber Daya Alam Menurut Undang-Undang Pokok Agraria Tahun 1960, Jurnal IUS (Hukum dan Keadilan). Vol 1. No.1.

Putri A.R. 2011.Perlindungan Hukum Terhadap Notaris (Indikator Tugas-Tugas Jabatan Notaris yang Berimplikasi Perbuatan Pidana). Sofmedia. Jakarta.

Soerjono Soekanto dan Sri Mamudji. 1990.Penelitian Hukum Normatif: Suatu Tinjauan Singkat.Rajawali Pers. Jakarta.

Subekti. 1990.Hukum Perjanjian. Intermasa. Jakarta. 1992. Pokok -Pokok Hukum Perdata,Cet. 24, PT. Intermassa, Jakarta.

\section{Peraturan Perundang-Undangan}

Kitab Undang-Undang HukumPerdata/KUHPerdata.

Undang-Undang Nomor 25 Tahun 2007 Tentang Penanaman Modal.

Undang-Undang Nomor 40 Tahun 2007 Tentang Perubahan Atas Undang-Undang Nomor 1 Tahun 1995 Tentang Perseroan Terbatas.

Undang-Undang Nomor 2 Tahun 2014 Tentang Perubahan Atas Undang-Undang Nomor 30 Tahun 2004 Tentang Jabatan Notaris (UUJN).

\section{Tesis, Jurnal dan Makalah}

Bismar Nasution. 2003.Metode Penelitian Hukum Normatif dan Perbandingan Hukum, Makalah FH USU. 
Fransiskus Sinaga. 2013.Prinsip Kemandirian Notaris Dalam Pembuatan Akta Otentik, Tesis Magister Kenotariatan. Universitas Sumatera Utara.

Ihdina Nida Marbun. 2015.Tanggung Jawab Notaris Terhadap Covernote (Surat Keterangan) Atas Pengurusan Sertipikat, Tesis Magister Kenotariatan. Universitas Sumatera Utara.

Jaya Kesuma. 2016.Perjanjian Nominee Antara Warga Negara Indonesia Dengan Warga Negara Asing Dalam Praktik Jual Beli Tanah Dihubungkan Dengan Undang-Undang Pokok Agraria Nomor 05 Tahun 1960. Jurnal Unpas.

M.Edwin Azhari dan Djauhari. 2018.Tanggung Jawab Notaris Dalam Pembuatan Akta Perjanjian Nominee Dalam Kaitannya Dengan Kepemilikan Tanah Oleh Warga Negara Asing Di Lombok. Jurnal Akta Vol 5 Magister Kenotariatan Fakultas Hukum Unissula.

Mujib Medio Annas. 2019.Analisis Yuridis Kepemilikan Hak Atas Tanah Yang Di Peroleh Berdasarkan Akta Jual Beli Yang Bersumber Dari Akta Perjanjian Pengikatan Jual Beli Dan Akta Kuasa Jual Yang Telah Dibatalkan (Studi Putusan Mahkamah Agung Nomor 1681K/Pdt/2015). Tesis Magister Kenotariatan, Universitas Sumatera Utara.

Peter Mahmud Marzuki. 2003. Batas-Batas Kebebasan Berkontrak, Fakultas Hukum Universitas Airlangga. Volume 18.Nomor 3.

\section{Internet}

https://m.hukumonline.com/berita/baca/lt5a5c2fbdae8c4/pelaksanaan-suatuperjanjian/

http://www.definisimenurutparaahli.com/pengertian-itikad-baik/ https://prezi.com/hnxfyetn5m-q/penyelundupan-hukum/ www.negarahukum.com/hukum/asas-asas-perjanjian.html 